\title{
Chemical Control of Mesquite Regrowth of Different Ages
}

\author{
DANNY L. BECK, RONALD E. SOSEBEE, AND E. B. HERNDON
}

\begin{abstract}
Highlight: Herbicide effectiveness on different age resprouts of honey mesquite was studied in the Rolling Plains of Texas. Herbicide treatments consisting of 2,4,5-T amine, 2,4,5-T ester, and Tordon 225 Mixture were applied monthly (May 15, 1972, through August 15, 1972) to trees shredded in 1971, 1965, and 1958. Tordon 225 Mixture was most effective on resprouts of all ages throughout the study. Trees sprayed in May and June had a higher percent root mortality than trees sprayed in either July or August.
\end{abstract}

Thousands of acres of mesquite (Prosopis) infested rangeland have received some form of control treatment. Yet, mesquite continues to reinfest these acreages and encroach onto rangeland previously not infested with mesquite. If a control program is to be successful, it must include maintenance treatments (Ames, 1966). Tschirley (1962) reported that two herbicide treatments applied to velvet mesquite ( $P$. velutina) either during consecutive years or at an interval of 1 or 2 years were more successful than single applications.

Effectiveness of chemical control of mesquite following some previous treatment is apparently dependent upon the age of resprouts and their stage of development. Although no studies have been conducted to determine the optimum time interval between treatment and re-treatment, some observations have been made. Presently, the recommendations are to repeat aerial spraying every 5 to 7 years (Meadors et al., 1973). Presumably, trees at least $4 \mathrm{ft}$ in height are more effectively controlled by aerial spraying than trees 2 to $3 \mathrm{ft}$ in hieight (Robison, 1963; Hoffman, 1973; Meadors et al., 1973). Hence, this study was initiated to measure herbicide effectiveness on honey mesquite ( $P$. glandulosa var. glandulosa) resprouts 1,7 , and 14 years old.

\section{Experimental Procedures}

Chemical control of three age groups of honey mesquite regrowth was studied in the Rolling Plains of Texas. Herbicide treatments were applied to 1- and 14-year-old resprouts (mature trees shredded in 1971 and 1958, respectively) located on the Bethel Ranch 7 miles south of Quanah. Similar treatments were applied to 7-year-old resprouts (mature trees shredded in 1965) located on the Koch Ranch 14 miles west of Quanah. The trees of both areas were growing on a range site transitional between a deep hardland and a shallow clay characterized by clay to clay loam soils of the Tillman-Vernon series (Lofton et al., 1972). The soil is deep to shallow with a

Authors are research assistant and associate professor of range management, Department of Range and Wildlife Management, Texas Tech University, Lubbock, 70409; and research associate, Department of Range and Wildlife Management, Texas Tech University, Quanah, 79252. At present Beck's address is P.O. Box 521, Throckmorton, Texas 76803 .

Research is a contribution of the College of Agricultural Sciences, Texas Tech University No. T-9-147.

The authors wish to gratefully acknowledge the cooperation of Mrs. Koch and Mr. Bethel (ranchers), the Dow Chemical Company, and Colloidal Products in this study.

Manuscript received November $21,1974$. clay loam surface layer. It is slowly to moderately permeable in the lower layers. The topography of both areas is nearly level to gently sloping. The vegetation was predominantly honey mesquite and tobosa grass (Hilaria mutica).

Regrowth of the different age groups ranged in height from $3 \mathrm{ft}$ (1-year-old resprouts) to 8 to $10 \mathrm{ft}$ (7- and 14-year-old resprouts). The trees were permanently marked for future reference. Treatments were applied monthly from May 15, 1972, through August 15, 1972. Each treatment was replicated 15 times (one tree constituted a replication). No tree was sprayed more than once.

Herbicide treatments consisted of 2,4,5-T (2,4,5-Trichlorophenoxyacetic acid) trimethylamine salt (Veon $245^{1}$ ), 2,4,5-T propylene glycol butyl ether esters (Esteron $245^{1}$ ) and picloram (4-amino-2,5,6-Trichloropicolinic acid) plus 2,4,5-T (Tordon 225 Mixture $^{1}$ ). The herbicides were mixed according to the manufacturer's recommendations and applied with a compressed air garden sprayer. Basically, the esteron $2454 \mathrm{lb}$ A.E./gal) mixture consisted of $1 \mathrm{oz}$ of herbicide dissolved in 1 $\mathrm{oz}$ of diesel oil with water added to a volume of $1 \mathrm{gal}$. One ounce of Veon 245 ( $4 \mathrm{lb}$ A.E./gal) and $2 \mathrm{oz}$ of Tordon 225 Mixture (2 lb A.E./gal) were dissolved in 1 gal of water. All mixtures were equivalent to $3 \mathrm{lb}$ of herbicide per $100 \mathrm{gal}$ of solution. A surfactant (Tronic ${ }^{1}$ ) was added to each herbicide solution to approximate $0.02 \%$ of the total volume.

Soil temperature, soil water content, air temperature, and relative humidity were measured at the time of herbicide application. Soil temperature was measured with a mercuryfilled thermometer placed in the soil at $6-, 12-, 18-$, and 24 -inch depths. Soil water content $(\%)$ was measured gravimetrically from samples taken in 6-inch increments to a depth of 24 inches. Relative humidity was measured with a sling psychrometer. The stage of phenological development of each tree was evaluated at the time of spraying.

Root mortality was evaluated during the fall, 1973. Since the tops of the trees were killed by spraying, generally the new growth originated at the basal crown. Any stem or basal sprouting constituted live trees. The data were analyzed by chi-square analysis and statistical differences were denoted at the $95 \%$ confidence level between herbicides and regrowth ages, separately for each month.

\section{Results and Discussion}

Control of regrowth in this study was primarily dependent upon the herbicides applied and the date of application (Fig. 1).

Resprouts sprayed in May were easily controlled by the various herbicide treatments, although the soil temperature (18-inch depth) was below the recommended level $\left(75^{\circ} \mathrm{F}\right.$ or $24^{\circ} \mathrm{C}$ ) for spraying (Dahl et al., 1971). Percent root mortality was greatest from plants sprayed with Tordon 225 Mixture but there were few differences among age groups. One-year-old resprouts sprayed in May possessed both mature and immature leaves. A few yellow and white flowers were present on the trees sprayed but the majority of the trees had flower spikes

${ }^{1}$ Use of trade names does not constitute endorsement by the authors or Texas Tech University. They are used for the convenience of the reader. 
Table 1. Climatic data and phenology of the different ages of honey mesquite regrowth on the dates of herbicide application in 1972.

\begin{tabular}{|c|c|c|c|c|c|c|c|c|c|c|c|c|c|}
\hline \multirow{2}{*}{$\begin{array}{c}\text { Date of } \\
\text { herbicide } \\
\text { application }\end{array}$} & \multirow{2}{*}{$\begin{array}{l}\text { Age of } \\
\text { resprout } \\
\text { (years) }\end{array}$} & \multirow{2}{*}{$\begin{array}{c}\text { Predominant stage } \\
\text { of phenological } \\
\text { development }\end{array}$} & \multirow{2}{*}{$\begin{array}{l}\text { Abundance } \\
\text { of flowers/ } \\
\text { trees }(\%)\end{array}$} & \multicolumn{4}{|c|}{$\begin{array}{c}\text { Average soil } \\
\text { temp. }\left({ }^{\circ} \mathrm{C}\right) \text { at various } \\
\text { depths (inch) }\end{array}$} & \multicolumn{4}{|c|}{$\begin{array}{l}\text { Average soil water } \\
\text { content (\%) at various } \\
\text { depths (inch) }\end{array}$} & \multirow{2}{*}{$\begin{array}{c}\text { Air } \\
\text { temperature } \\
(\mathrm{C})\end{array}$} & \multirow{2}{*}{$\begin{array}{c}\text { Relative } \\
\text { humidity } \\
(\%)\end{array}$} \\
\hline & & & & 6 & 12 & 18 & 24 & $0-6$ & $6-12$ & $12-18$ & $18-24$ & & \\
\hline May 15 & 1 & $\begin{array}{l}\text { most leaves dark } \\
\text { green; spikes } 1 / 4-1 / 2 \\
\text { extended }\end{array}$ & 25 & 20.0 & 20.3 & 20.7 & 19.9 & 13.5 & 8.0 & 7.9 & 6.9 & 29 & 35 \\
\hline May 17 & 7 & $\begin{array}{l}\text { leaves dark green; } \\
\text { spikes } 1 / 4-1 / 2 \text { ex- } \\
\text { tended; some white } \\
\text { flowers; few pods }\end{array}$ & 65 & 27.7 & 23.5 & 22.4 & 21.7 & 12.0 & 10.3 & 10.8 & 11.3 & 32 & 34 \\
\hline May 16 & 14 & $\begin{array}{l}\text { leaves dark green; } \\
\text { white and yellow } \\
\text { flowers; few pods }\end{array}$ & 31 & 26.1 & 23.8 & 23.1 & 21.3 & 13.5 & 11.5 & 10.7 & 11.2 & 30 & 40 \\
\hline June 14 & 1 & $\begin{array}{l}\text { most flowers abort.; } \\
\text { pods } 3-6^{\prime \prime} \text { long }\end{array}$ & 11 & 29.9 & 26.5 & 25.5 & 25.4 & 11.3 & 11.3 & 12.1 & 12.8 & 31 & 57 \\
\hline June 17 & 7 & $\begin{array}{l}\text { most flowers abort.; } \\
\text { pods } 3-6^{\prime \prime} \text { long }\end{array}$ & 34 & 26.3 & 26.8 & 26.6 & 26.2 & 12.4 & 9.2 & 9.9 & 10.5 & 30 & 53 \\
\hline June 13 & 14 & $\begin{array}{l}\text { most flowers abort.; } \\
\text { pods } 3-6^{\prime \prime} \text { long }\end{array}$ & 24 & 26.3 & 26.0 & 25.5 & 25.0 & 9.3 & 11.1 & 12.0 & 12.0 & 27 & 64 \\
\hline July 12 & 1 & $\begin{array}{l}\text { many new leaves; } \\
\text { most } 1 / 4-1 / 2 \text { extended; } \\
\text { few pods }\end{array}$ & ; & 32.9 & 29.5 & 29.0 & 28.1 & 7.3 & 8.3 & 10.1 & 8.5 & 37 & 33 \\
\hline July 11 & 7 & $\begin{array}{l}\text { no new leaves; all } \\
\text { pods beginning to } \\
\text { mature }\end{array}$ & 31 & 29.1 & 28.7 & 28.4 & 27.8 & 12.7 & 10.3 & 13.1 & 13.1 & 31 & 66 \\
\hline July 11 & 14 & $\begin{array}{l}\text { no new leaves; all } \\
\text { pods beginning to } \\
\text { mature }\end{array}$ & 31 & 29.7 & 30.6 & 30.1 & 28.8 & 6.0 & 7.7 & 8.6 & 7.7 & 24 & 73 \\
\hline Aug. 15 & 1 & $\begin{array}{l}\text { no new leaves; most } \\
\text { flowers aborted; } \\
\text { pods } 3-6 \text { " long }\end{array}$ & 11 & 27.5 & 27.9 & 27.8 & 28.1 & 12.9 & 10.2 & 10.7 & 10.7 & 31 & 54 \\
\hline Aug. 14 & 7 & $\begin{array}{l}\text { pods matured and } \\
\text { fallen from tree }\end{array}$ & 0 & 27.6 & 28.3 & 29.2 & 28.0 & 12.7 & 8.7 & 9.1 & 9.1 & 30 & 67 \\
\hline Aug. 14 & 14 & $\begin{array}{l}\text { pods matured and } \\
\text { fallen from tree }\end{array}$ & 0 & 27.8 & 29.0 & 28.6 & 28.7 & 9.7 & 7.6 & 9.8 & 10.6 & 27 & 63 \\
\hline
\end{tabular}

that ranged from closed to fully extended but not blooming. The phenological stage of the 7-and 14-year-old resprouts was more advanced than that of the 1 -year-old resprouts.

By mid-June, the soil temperature (18-inch depth) had warmed to approximately $77^{\circ} \mathrm{F}\left(25^{\circ} \mathrm{C}\right)$. Most flowers on resprouts of all ages had aborted; others had developed immature pods 3 to 6 inches long. Root mortalities (\%) obtained from spraying with Tordon 225 Mixture were significantly greater than those obtained from spraying with either 2,4,5-T amine or 2,4,5-T ester. There were no significant differences among percent root mortalities of the different age groups.

Excellent control was obtained by spraying 7-year-old resprouts with Tordon 225 Mixture in mid-July. By contrast, other treatments applied during this period were much less effective. Most trees possessed maturing pods at this time; however, the 1-year-old resprouts had put out many new leaves and young, immature flower spikes. Stem sprouts were present in the fall, 1973, on approximately $11 \%$ of the trees sprayed during July, 1972.

Effectiveness of herbicides applied in August was erratic. The amine formulation of 2,4,5-T applied to any age of resprouts was totally ineffective. Effective resprout control during August with either 2,4,5-T ester or Tordon 225 Mixture was dependent upon the age of resprouts. Trees sprayed in August but not root-killed were characterized by abundant stem sprouting in the fall, 1973.
Since the climatic and soil conditions were very similar for all sites on a particular spray date in this study (Table 1), the reason the kill was greater on one age of regrowth than on another is not readily apparent. However, some of the differences in kill may possibly be explained by Crafts (1964). Even though fully expanded leaves offer the greatest surface area for uptake of herbicides, green or succulent stems may also absorb these compounds. Therefore, when systemic herbicides are used, the amount of herbicides reaching the effective sites from stem absorption (since the stems are closer to the desired sites of action in the roots) may migrate directly to the sieve cells and move out via the phloem. The 1 -year and possibly some of the 7-year-old resprouts which were treated possessed new green succulent stems throughout the study. These differences in absorption between the leaf and stem may account for some of the higher kills on the younger resprouts in this study.

\section{Conclusions}

Mesquite regrowth (1 to 14 years old) in the Rolling Plains of Texas was effectively controlled with herbicides applied during May and June, 1972, prior to pod maturity. However, similar age regrowth sprayed during July or August was not effectively controlled. Tordon 225 Mixture was clearly more effective than either 2,4,5-T amine or 2,4,5-T ester in controlling the different ages of regrowth. Tordon 225 Mixture was also more effective when sprayed in July and 

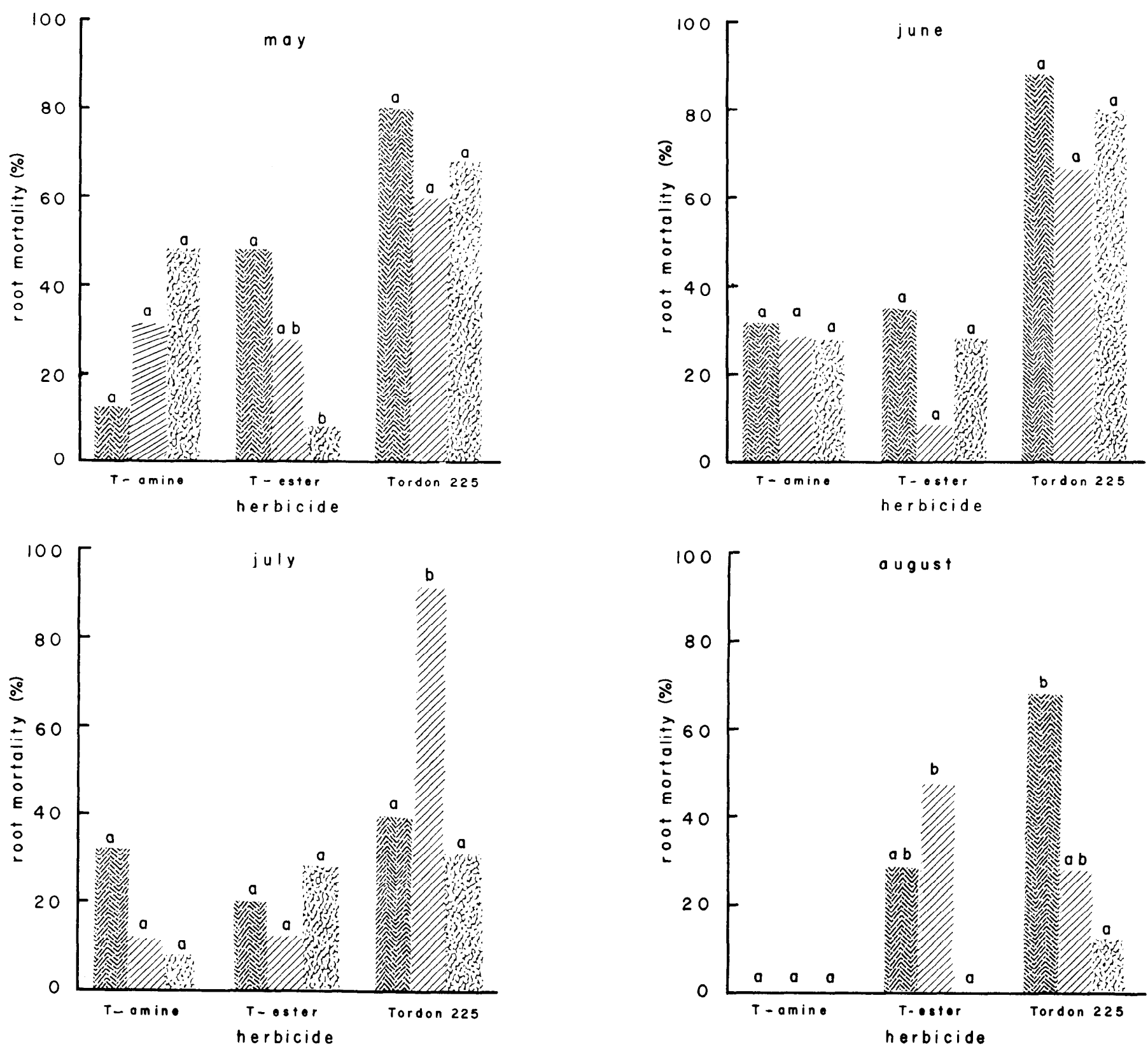

Fig. 1. Average root mortality (\%) of 1-, 7-, and 14-year-old regrowth of honey mesquite sprayed with 2,4,5-T amine, 2,4,5-T ester, and Tordon 225 Mixture during 4 months in 1972. Bars having the same lower case letters were not significantly different (0.05 level).

August than either the amine or ester formulation of 2,4,5-T. The age of regrowth, between 1 and 14 years, had less effect on root mortality caused by spraying than the kind of herbicide used or the time of spraying.

\section{Literature Cited}

Ames, C. P. 1966. Mesquite control on the Coronado National Forest. J. Range Manage. 19:148-150.

Crafts, A. J. 1964. Herbicide behavior in the plant, p. 75-108. In: L. S. Audus (ed.). The physiology and biochemistry of herbicides. A cademic Press, New York.

Dahl, B. D., R. B. Wadley, M. R. George, and J. L. Talbot. 1971. Influence of site on mesquite mortality from 2,4,5-T. J. Range
Manage. 24:210-215.

Hoffman, G. O. 1973. Putting research into action-guidelines for mesquite control, p. 71-74. In: C. J. Scifres. Mesquite. Research Monogr. 1, Texas Agr. Exp. Sta.

Lofton, K. T., E. Blakely, and M. L. Dixon. 1972. Soil survey of Hardeman County, Texas. Soil Conserv. Serv., U.S. Dep. Agr. 25 p.

Meadors, C. H., C. E. Fisher, R. H. Haas, and G. O. Hoffman. 1973. Combinations of methods and maintenance control of mesquite, $\mathrm{p}$. 53-59. In: C. J. Scifres. Mesquite. Research Monogr. 1, Texas Agr. Exp. Sta.

Robison, E. D. 1963. Chemical brush control in West Texas. Texas Agr. Progr. 9:3-5.

Tschirley, F. H. 1962. Controlling mesquite with 2,4,5-T. Univ. of Arizona, College of Agr. Folder 98.6 p. 